2016-06

\title{
Environmental Impact Assessment: \\ Gathering experiences from wave energy test centres in Europe
}

Greaves, Deborah

http://hdl.handle.net/10026.1/4563

10.1016/j.ijome.2016.02.003

International Journal of Marine Energy

Elsevier BV

All content in PEARL is protected by copyright law. Author manuscripts are made available in accordance with publisher policies. Please cite only the published version using the details provided on the item record or document. In the absence of an open licence (e.g. Creative Commons), permissions for further reuse of content should be sought from the publisher or author. 
1 Greaves, D., Conley, D., Magagna, D., Aires, E., Chambel Leitão, J., Witt, M., Embling, 2 C.B., Godley, B.J., Bicknell, A., Saulnier,J-B., Simas, T., O'Hagan, A.M., O'Callaghan,

3 J., Holmes, B., Sundberg, J., Torre-Enciso,Y., Marina, D., (2015) Environmental Impact 4 Assessment: gathering experience at wave energy test centres in Europe, accepted for 5 publication in IJME. doi:10.1016/j.jome.2016.02.003

\section{Environmental Impact Assessment: gathering 7 experiences from wave energy test centres in Europe}

\section{Authors}

Deborah Greaves ${ }^{1}$, Daniel Conley ${ }^{1}$, Davide Magagna ${ }^{1}$, Eduardo Aires ${ }^{2}$, José Chambel Leitão ${ }^{2}$,

Matthew Witt ${ }^{3,4}$, Clare B. Embling ${ }^{3,4}$, Brendan J. Godley ${ }^{3,4}$, Anthony W. J. Bicknell ${ }^{3,4}$, Jean-

Baptiste Saulnier ${ }^{5}$, Teresa Simas ${ }^{6}$, Anne Marie O'Hagan ${ }^{7}$, John O'Callaghan ${ }^{7}$, Brian Holmes ${ }^{7}$, Jan

Sundberg $^{8}$, Yago Torre-Enciso ${ }^{9}$, Dorleta Marina ${ }^{9}$

\section{Authors' affiliation and address}

${ }^{1}$ School of Marine Science and Engineering and Marine Institute, Plymouth University, Drake

Circus Plymouth PL4 8AA, United Kingdom

${ }^{2}$ HIDROMOD, Rua Rui Teles Palhinha, nㄴ, 1으, 2740-278, Porto Salvo, Portugal

${ }^{3}$ Environment and Sustainability Institute University of Exeter, Penryn Campus, Penryn,

Cornwall, TR10 9FE, United Kingdom

${ }^{4}$ Centre for Ecology and Conservation, University of Exeter, Penryn Campus, Penryn, Cornwall,

${ }^{6}$ WavEC, Offshore Renewables, Rua Jerónimo Osório, 11, 10 andar, 1400-119, Lisboa, Portugal 
${ }^{8}$ Uppsala University, Swedish Centre for Renewable Electric Energy Conversion, Dept. Of

$27{ }^{9}$ Ente Vasco de la Energía, Alameda de Urquijo, 36 1ํ, Edificio Plaza Bizkaia, 48011 Bilbao,

28 Spain

\section{Corresponding author}

30 Prof. Deborah Greaves

$31 \quad$ E-mail: deborah.greaves@plymouth.ac.uk

32 Telephone: $+44(0) 1752586122$

\section{Abstract}

34 The wave energy industry is an emerging sector and a new user of maritime space that has

35 potential to contribute significantly to the EU renewable energy goals. International and national regulatory frameworks necessitate Environmental Impact Assessments (EIA) that provide important data to inform development consent decisions. Here we have evaluated experience related to the assessment programmes at EU wave energy test centres combined with knowledge gained from EIA produced for other similar renewable energy developments. From this we have identified key receptors of concern, as well as the type and magnitude of

41 impacts which may be expected. The key environmental receptors of concern for wave energy EIA include the physical environment (e.g. morphology, waves and current) and flora and fauna ${ }^{1}$ as represented by marine mammals, seabirds, benthos, fish and shellfish. regarding the wave energy EIA process. There is clear evidence that the receptors of primary

\footnotetext{
${ }^{1}$ The term 'flora and fauna' is used in the Environmental Impact Assessment (EIA) Directive (2011/92/EU consolidated version) - Article 3. The newly amended EIA Directive (2014/52/EU) entered into force on 15 May 2014 and uses the term 'biodiversity' as opposed to flora and fauna.
} 
46 interest are dependent on factors such as the local environmental characteristics, the

47 presence/absence of protected species and the regulatory authority under which the EIA is

48 performed. Furthermore, it is recommended that concerns relating to cumulative impacts,

49 from an expanding level of wave energy development taking place in a background of growing

50 utilisation of the marine environment, which are largely unknown at this early stage of the

51 industry may be comprehensively addressed at the national level as part of a Strategic

52 Environmental Assessment (EIA) and/or in Maritime Spatial Planning (MSP) and that it should

53 be regularly reassessed.

54

55

\section{Keywords}

57 Wave energy; Europe; Test Centres; Environmental Impact Assessment; receptors;

58 recommendations. 


\section{Introduction}

61 The wave energy industry is an emerging sector and, in comparison with more established

62 industries, is a new user of maritime space. The potential of wave energy to contribute towards EU renewable energy goals and climate change mitigation have long been discussed (Cruz, 2008; Falcão, 2008; Clément et al., 2002). However, technical and non-technical barriers still need to be overcome in order for wave energy to become an established energy source.

A particular non-technical barrier experienced across Europe by different device and site developers is the necessity of this new industry to abide by EU and national regulatory frameworks for planning and development consents. In particular, wave energy developers need to comply with the EU Environmental Impact Assessment (EIA) Directive and associated national legislation, which necessitates the collection and collation of environmental data in order to enable regulatory authorities to make an informed decision on the proposed project and its potential environmental impacts at an early stage.

In the EU, the EIA process is codified in Directive 2011/92/EU and amended by 2014/52/EU, which defines the framework for the EIA process. The Directive identifies the projects subject to mandatory EIA (Annex I), and those for which EIA can be requested at the discretion of the Member States (Annex II), whereby the national authorities have to decide whether or not an EIA is needed.

The EIA process requires developers to supply comprehensive environmental data relating to both baseline conditions and possible environmental impacts of device installation. Given the novelty of wave and tidal energy device deployments, many effects and impacts are unknown and have not been quantified as yet (Langhamer et al., 2010). This has resulted in a number of gaps in the information, data and knowledge available to regulatory authorities and developers. One significant problem constraining wave energy project development is definition of the scope of the EIA, e.g. what kinds of data are collected, the resolution required 
for each type of data and the timescale of any subsequent monitoring programme (Muñoz Arjona et al., 2012). These uncertainties can have a substantial impact on the cost of a project whilst also possibly causing delays to the project's development.

Various studies have been conducted to evaluate the potential change in waves through an array of wave energy converters (WECs) based on wave propagation and simplified hydrodynamic models (e.g. Millar et al., 2007; Smith et al., 2012; Rusu and Guedes Soares, 2013). Preliminary studies generally conclude that the change in significant wave height alongshore due to the presence of an array of wave energy devices is unlikely to exceed a few percent. The largest effects of absorption will be experienced immediately downstream of the array where wave energy, period and spreading are most likely to be modified. The combined effects of wave spreading and diffraction will then lead to reductions in these alterations as distance from the array increases so that the net effect on distant shorelines can be quite small. Smith et al. (2012) argue that the changes which will eventually be observed are likely to be overestimated by these simulations due to the high rates of device energy absorption generally assumed in the modelling.

There are both potential positive and negative impacts of wave energy developments on cetaceans (Witt et al., 2012), and a number of reviews have assessed the potential impacts of MRE infrastructure on marine mammals (Lucke et al., 2006; Madsen et al., 2006; Simmonds and Brown 2010; Witt et al., 2012, Inger et al., 2009, Truebano et al., 2013). The main perceived risks are collision/entanglement, displacement, electromagnetic fields, noise and cumulative effects. Nonetheless, studies are still scarce and potential impacts have been largely hypothesised. There is also a high level of uncertainty regarding whether the documented responses may lead to impacts at the population level (MacLean et al 2014).

In recent years, sound from human activities such as shipping, seismic surveys and seabed drilling have increased the ambient noise level in certain areas (Hildebrand, 2004). Many 
marine species use sound for communication, navigation, finding prey and evading predators

111 (see e.g. Richardson et al. 1995) and different species detect and emit sound over a broad range of frequencies and amplitudes. Because of their dependence on sound, it is possible that the additional noise added to the underwater environment from the construction and operation of marine renewable energy devices and farms could have an effect on these underwater species.

Potential environmental impacts of ocean energy have already been identified in a number of papers and reports (e.g. Inger et al., 2009; Langhamer et al., 2010; Kadiri et al., 2012; Frid et al., 2012). However, the quantification of the real effects of technologies on the marine environment are site specific and still need to be assessed during device operation through the implementation of monitoring programmes. This paper is based on work carried out during the EU IEE-funded project Streamlining of Ocean Wave Farm Impact Assessment (SOWFIA) and aims to examine the EIA experience gathered at wave energy test centres across Europe. Key receptors are identified as well as principal findings from the test centres in order to help reduce uncertainties and facilitate the performance of EIAs of wave energy projects. Socioeconomic factors are not considered in detail here, but are discussed by Simas et al. (2013). The term receptors is used to define individual components of the environment likely to be affected by the development, including flora, fauna, soil, water, air, climatic factors, and material assets such as the architectural and archaeological heritage, landscape and the interrelationship between these factors.

\section{EIA for wave energy test centres in Europe}

\subsection{Study sites} Ireland (Cahill, 2013), BIMEP in Spain (Marqués et al., 2008), Lysekil in Sweden (Parwal et al. 
135 (Mouslim et al., 2009) and Wave Hub in the UK (Harrington and Andina-Pendás, 2008).

\subsection{Data assimilation}

Data gathered from monitoring activities in each test centre have been uploaded to a Data

paper is based on data from monitoring activities at the six test centres listed above, but the

DMP was also populated with some data available from other European test centres, e.g. the (Magagna et al., 2012). Data were divided into three main categories:

- Studies on physical factors (e.g. geomorphology, hydrodynamics and water quality);

- Studies on biological factors (e.g. benthos, marine mammals, fish and seabirds);

These categories provide a broad envelope for monitoring of the eleven descriptors of Good for each category and test centre is summarised below, including the relevant potential effects of wave energy farms on the marine environment.

\subsubsection{Physical factors}

156 Coastal processes involve erosion, transportation and deposition of sediments controlled by

157 the hydrodynamic pattern in a given coastal area. The removal of energy from the marine 
environment due to the presence of wave energy devices has been identified as a potential negative effect of this group of technologies. Changes in the wave energy may influence the transport of gases, nutrients and food for some species and interfere with the distribution of others with dispersive juvenile stages reliant on transport by currents (e.g. Nowell and Jumars, 1984; Koehl, 1996; Abelson and Denny, 1997; Gaines et al., 2003; Gaylord, 2008). Furthermore, the long shore transport of material (and thus the sites where sediment accumulates or erodes) is dependent on the size and direction of incoming waves. Thus, by reducing waves in general and particularly those from a specific direction (i.e. downstream of the device), long shore drift of material and ultimately beach morphology, shallow water bathymetry and substrata may be altered (Defeo et al., 2009; Shields et al., 2011). Theoretical models of wave energy farms consisting of 270 devices, with about $200 \mathrm{MW}$ total installed power and moored in 50 to $70 \mathrm{~m}$ water depth off the coast of Portugal, indicated that the significant wave height at the $10 \mathrm{~m}$ depth contour may be reduced by $5 \mathrm{~cm}$, when considering a monthly mean significant wave height range of 1.3 to $2.9 \mathrm{~m}$. The research also found that the relative percentage of wave energy removal by the devices will be greatest during the summer (Palha et al., 2010).

In terms of the vessels and equipment used to install and remove wave energy test centres' infrastructure and wave energy converters, the principal types of substances that pose a risk to water quality are fuels, lubricants and coolants (used in hydraulic fluids and painting of devices). Furthermore the seabed disturbance during test centre construction and device installation (e.g. cable burial and installation of mooring systems) may increase sediment suspension and water column turbidity decreasing light penetration and interfering with primary production (e.g. phytoplankton, algae, seagrasses, kelp). 


\subsubsection{Biological factors}

182 As mentioned above, wave energy devices have the potential to impact marine mammals, and possible adverse impacts might include collision, entanglement, entrapment, noise, habitat disturbance and electromagnetic fields as described by Cada et al. (2007), Dolman et al. (2007), Ortega-Ortiz and Lagerquist (2008). In addition, installation of wave energy developments in the marine environment will bring new sources of noise, and this may interfere with marine mammal species that use sound for communication, navigation, foraging and evading predators (e.g. Richardson et al., 1995; Patrício et al., 2009; Croxall, 1987).

The diversity of seabird species utilising European marine, coastal and offshore habitats is considerable. It is expressed in many forms, including feeding method (from deep diving species, like gannets, to surface foragers such as petrels), preferred flight heights, migratory period and selected routes, young rearing behaviour, selection of mates and foraging distances from breeding colonies (Croxall, 1987, Scott et al., 2014).

Due to the lack of information and data, impacts of wave energy devices on seabirds are mostly extrapolated from those observed in offshore wind farms (McCluskie et al., 2012 ), although wind and wave energy technologies represent quite different physical stressors (Langton et al., 2011; Lindeboom et al., 2011). Suggested effects included (negative and positive) are disturbance (e.g. noise, interference with foraging due to water turbidity increase during installation), collision, barrier effects to migration, habitat modification (which can include new roosting and foraging sites), loss and entrapment (Wilson et al., 2007; Witt et al., 2012; Cruz and Simas, 2012, Grecian et al., 2010). Clearly there are noteworthy differences between the potential impacts on birds of offshore wind farms and wave energy farms. Collision risks with offshore wind farms, tall static towers or large blades with high tip speed, cannot be compared to collision risks with wave-energy devices, with different structures under water and no or only slowly moving parts, but there are also likely to be degrees of similarity. For example, the effects of disturbance during installation, habitat modification, 
barrier and displacement effects are likely to show similarities for offshore wind and wave energy farms, as may future cumulative effects due to the factors mentioned here.

209 Benthos is the community of organisms which live on, in, or near the seabed. In temperate

210 waters, the intertidal and subtidal hard bottom benthic communities frequently colonise up to

$211100 \%$ of the area of available substratum (Pohle and Thomas, 1997). The benthos is usually a major consideration in biodiversity conservation since its study helps the understanding of changes in biological diversity caused by natural or anthropogenic factors. The hydrodynamic regime, in combination with sediment source, determines the characteristics of seabed sediment distribution and this ultimately determines a significant part of the broad scale community patterns observed (Judd, 2012), and so any change in hydrodynamics due to the presence of wave energy devices may impact benthic communities. their abundance and distribution close to a wave farm. Such changes can have implications on fishing activities which need to be assessed (e.g. Simas et al., 2013). The potential impacts from the development of offshore wave farms on fish include: collision mortality (generally low risk depending on the technology employed), physical habitat modification, acoustic trauma and barrier effects due to electromagnetic effects (EMF). Positive benefits may include structures forming artificial reefs (ARs) and/or fish aggregating devices (FADs) for pelagic fish

225 (Langhamer et al., 2009).

\subsubsection{Socio-economic factors}

In general the main socio-economic activities identified in the vicinity of the wave energy test centres under study are fishing, navigation and tourism. Industry is also referred to in some reports as an important socio-economic activity but impacts of wave energy deployment on it are all considered positive in terms of sector development in the region and job creation. 
231 Socio-economic factors are not considered further here, but are discussed by Simas et al.

232 (2013).

233

234

235

\subsection{Review of Environmental Impact Assessment reports}

A detailed review of the EIA reports to assess the perceived magnitudes of the impacts on environmental receptors included in each EIA report for each wave energy test centre were reported by Simas, et al. (2013). Following on from this we have attempted to homogenise the perceived magnitudes of these impacts by adopting the following classification across all ElAs:

- Compatible impact: impact that can recover immediately after cessation of the activity and that does not need any protective measure(s);

- Moderate impact: impact that can recover without any protective or corrective intensive practices and where restoring the initial environmental conditions takes some time;

- Severe impact: impact that needs some adequate protective and corrective measures to restore the initial environmental conditions, which requires significant time;

- $\quad$ ritical impact: impact whose magnitude is above the acceptable threshold. It produces permanent impairment of the environmental conditions.

\section{Comparison of EIA for wave energy test centres in Europe}

Table 1 shows the type of monitoring studies carried out in each wave energy test centre under study. It can be seen that the benthos is the most common EIA component and is characterised in all test centres, followed by hydrodynamics and marine mammals, which have been studied in five test centres.

TABLE 1 NEAR HERE 

evaluation of potential impacts is evident. Table 2 highlights the variation in evaluation of impacts between test centres. This depends on a complex combination of factors, discussed further below, including: the environmental conditions at each site, the presence of protected species and habitats and the location of each site relative to protected areas. It should be emphasised that these are potential impacts identified in the test centre EIAs before deployment of any devices and are not observed impacts. The different evaluations of potential impact at each site is partly due to different approaches in consenting authorities as well as site specific biological and/or socio-economic characteristics between the included countries and the test centres.

Furthermore, the consenting process may have differences even within a country and these processes are likely to evolve as the industry develops. For example, when Uppsala University applied for permits and consent for the Lysekil project (Parwal et al. 2015), the Swedish Environmental Law was still quite new and there was provision for small projects to be developed without the need to undertake an extensive EIA. The team at Uppsala University were able to agree with the authorities, based on best knowledge, on which pre-construction and post-construction studies would be valuable and should be undertaken (Haikonen et al., 2013, Langhamer et al., 2009). However, the provision for small projects changed by the time the application was made for the ten year consent to be extended in 2013 , and in this case, a full scale EIA was required with specified studies as included in Table 1. In Ireland, in the EIA for the AMETS test centre (Cahill, 2013), the receptors considered for the physical environment were water quality and groundwater, physical processes, air quality and climate. The impacts on water quality and groundwater were considered to be moderate because the main effects are expected from suspended sediments during cable burial and 
anchoring operations; the impact on the physical processes was taken as compatible because it is expected that the impact of wave energy converters when deployed at the test area would be insignificant in comparison to the natural processes occurring; the impact on the air quality and climate was deemed compatible both in the national context and in the immediate receptor area.

Within flora and fauna, the environmental receptors assessed at AMETS were marine mammals, seabirds and benthos. The impact on the marine mammals was classified as moderate because, although the construction phase is likely to be the most disruptive to marine mammals due to increased noise and boat traffic, they are expected to return to the area once construction has been completed. Operational impacts are not deemed to be significant. The potential impacts on seabirds, which came from physical disturbance, risk of collision and noise disturbance, are speculative and they are expected to be minimised so the cumulative impact was classified as moderate. The general effects of the development on benthos, due to increased sediment transportation, is unlikely to have any more effect than a natural storm. The greatest potential impact in this regard is due to the creation of an artificial reef, which can on one hand increase biodiversity in the area, but on the other may fragment benthic communities. Nonetheless the extent of this was expected to be small in the context of the total available habitat so the impact was classified as moderate.

In Spain, at the BIMEP test site (Marqués et al., 2008), the receptors assessed within the EIA regarding the physical environment were water quality, groundwater and physical processes. The impact on the water quality and groundwater was considered compatible because the possible damage caused to the water during the installation, functioning and decommissioning of the WECs is considered minimal; the impact on the physical processes was severe because the device moorings were not expected to be removed following the testing period, but instead would remain in place. 
For the flora and fauna the descriptors considered by BIMEP were marine mammals, seabirds,

304 fish/shellfish and benthos. The impact on the marine mammals was assessed as severe because of the vibrations and noise produced mainly during the installation and decommissioning of the WECs and cables and, to a lesser extent, during the operation of the WECs. The impact on the seabirds was moderate because the birds can be affected by noise and vibrations during the installation, operation and decommissioning of both cables and WECs. Potential impact on the fish and shellfish due to vibrations and noise of installation and decommissioning was classified as moderate as was the impact due to electromagnetic fields. Research has identified the biological significance of electromagnetic fields to certain marine species (Gill et al., 2012), and although there has been no documented evidence of significant behavioural effect on a species level from existing installations, this uncertainty has led the authors of the EIA report to judge the potential impact as moderate whereas at other sites it is considered compatible (Conley et al. 2012). BIMEP's EIA required an in situ analysis of the electromagnetic fields generated by the subsea cables to be carried out to try to assess the real impact. The EMF study at BIMEP includes: modelling of the cable and its electromagnetic fields; design of the appropriate sensors to determine the magnetic and electric fields; measuring the electromagnetic fields generated by the subsea cable when buried, when lying on the seabed, and generated by connection boxes and the connectors. The increase in suspended sediments in the water was deemed a moderate impact on benthos while the dragging of the mooring and/or the anchors was considered a severe impact. environment, including water quality, groundwater and physical processes, compatible because both the increased sedimentation and the bio-fouling effect around and nearby the WECs were considered to be localised and could be equated with other, similar and common natural occurrences. For the flora and fauna category, the impacts on marine mammals, 
seabirds and benthos was considered compatible: in fact the Lysekil site and its surroundings do not host species of special interest or at least none that would be affected by the project.

330 At the Portuguese test centre Ocean Plug (Huertas-Olivares et al., 2007) only the flora and

331 fauna sensitivities were assessed and the impacts were deemed severe on both marine mammal and seabirds because of the presence of endangered species which can possibly be affected by the deployment and operation of wave energy devices. This example highlights the dramatic effect that project siting can impart on the EIA process.

The EIA analysis carried out to assess the potential impacts at the French SEM-REV test centre (Mouslim et al., 2009) under the physical environment includes water quality, groundwater and physical process parameters. The impact on water quality and groundwater was moderate because the water quality alteration due to fluid industrial waste and turbidity was deemed moderate and temporary using conventional mitigation measures. The impact on the physical processes was compatible because the modification of sedimentary dynamics was deemed moderate to negligible due to the limited footprint of impacted area, the low number of anchors and the weak nature of local sediment transport. For the flora and fauna, the receptors considered were marine mammals, seabirds, fish and shellfish and benthos. The impact on marine mammals, seabirds and fish and shellfish has been classified as compatible because disturbance during installation and operation is considered negligible due to the short duration of the works and limited number of WECs to be tested. Noise and electromagnetic effects are given as moderate to minor/negligible assuming the use of suitable mitigation measures, such as cable burying. The impact on the benthos was compatible, because the destruction of benthic species and micro and macro algae on the submarine cable route and on the test site itself, has been classified as reversible and negligible. category, water quality, groundwater and physical processes were included. The EIA 
documentation indicated that the impact of the site on water quality and groundwater was compatible. This is because the survey of water and sediment quality carried out to determine the baseline showed that no impact on water, soil or sediment quality will take place during construction, operation or decommissioning. The impact on the physical processes was compatible, because results of modelling showed that waves at the coast could be impacted by up to $13 \%$, but more typically in the order of $5 \%$ (Smith et al., 2012), and a minimal impact due to changed sediment transport on beaches could be expected along the northern Cornish coast.

Considering flora and fauna, assessed receptors were marine mammals, seabirds, fish and shellfish and benthos. The impact on marine mammals was compatible, because the installation of WEC anchors or moorings is likely to involve either pile driving or seabed drilling for some types of WEC (Witt et al., 2012). The impact of construction noise on marine mammals was considered to be of minor adverse significance, the impact on the seabirds was compatible, because no significant impacts on all birds present at the site are expected if appropriate mitigation measures are employed. Regarding fish and shellfish the most frequently recorded sensitive species is the basking shark and the main impact of concern was the electromagnetic fields generated by cables which were considered unlikely to cause damage. Nonetheless, considering the sensitivity of the species, the impacts were deemed compatible. The impact on the benthos was compatible because any disturbance to intertidal seabed communities from installation and decommissioning of the cable was considered to have minimal impact due to rapid re-colonisation of the surrounding seabed.

\section{Discussion of similarities and differences observed}

This review of EIA in the six European wave energy test centres highlights some clear differences and inconsistency among test centres. It should be noted that the EIA reports are analysed to assess perceived impacts on receptors and are not 'real' impacts. Evaluations of 
the severity of potential impacts given in the EIAs varies between different test centres partly due to different approaches in consenting authorities as well as biological/socio-economic differences. One observation evident from the review is the pronounced role that the presence of protected species plays in the EIA process. In the case of the Ocean Plug test centre, the presence of endangered species led to the potential impact on receptors (marine mammals and seabirds) being assessed as severe, whereas in all other test centres critically endangered species were not deemed present and the potential impact on marine mammals and seabirds was assessed as moderate or compatible.

Another aspect is the variability of sensitivity to various receptors under different regulatory regimes. Five of the seven selected receptors were not assessed in at least one centre and not one test centre assessed all of the receptors in its EIA. Another aspect highlighted in this review is that the potential impacts identified in the EIAs for essentially similar projects are different and shown to be dependent on the local environmental/political/regulatory landscape. This is demonstrated by the fact that six test centres, which may host the same device types, exhibit impact magnitudes for the same receptors ranging from compatible to severe. Potential impacts on air quality, climate, water quality and groundwater are uniformly perceived as having the lowest magnitude followed by physical processes. With one exception, potential impacts from EMF were not considered significant across the test centres. This classification usually exempts these impacts from the monitoring plan after deployment. In cases where cumulative impacts of several devices for a given component are important, their absence from the monitoring program may compromise the learning process for upscaling of impacts regarding large scale developments.

Key environmental receptors of potential concern for wave energy EIA are considered in this work. These receptors fall into one of two categories: the physical environment (waves and 
403 (Conley et al. 2012).

404 As regards hydrodynamics (waves and currents), the existing understanding is that arrays of

405 wave energy devices will lead to alterations in the energy level and spectral nature of incident

406 waves in the lee of such arrays but that these effects will diminish with distance from the

407 arrays. Preliminary studies suggest that a magnitude of change of no more than $10 \%$ can be expected.

As regards noise impacts, limited measurements from deployed WECs confirm that the emitted noise is likely to be limited to frequencies below a few tens of $\mathrm{kHz}$, that the signal strength varies with sea state and that the noise emitted would be detectable by some marine species.

The limited experience to date regarding the impact of MRE devices on marine mammals suggests that these animals may avoid such devices but further experience with different technologies in different settings is needed. Experience with nets and static (but slack) fishing gear indicates that entanglement is a potential issue although the risk associated with wave energy devices is likely to be much lower than with other MRE technologies, such as tidal turbines where collision is a potential issue. The risk is potentially aggravated by the increased availability of food arising from the potential FAD (fish aggregating devices) potential of WECs.

420 Because of the highly mobile nature of marine mammals, cumulative effects from increasing

421 MRE developments as well as other anthropogenic activities are of special concern and must

422 be carefully considered in the planning stages of a new development.

423 WECs have a much smaller above-water profile than wind turbines, and so are likely to present 424 a much lower collision risk to seabirds than offshore wind, but their considerable underwater structure may provide an enhanced collision or entrapment risk, particularly their moving 
parts. The most likely direct impact of WECs on birds is displacement. Species that are

427 restricted to foraging in specific habitats may be particularly vulnerable, but sensible site selection to avoid sensitive foraging areas will help mitigate possible population impacts.

429 The experience provided from test centre EIAs suggests that the effects of the deployment of

430 wave energy converters on coastal processes and geology would be insignificant in comparison with the natural processes occurring at the sites. Similarly, seabed disturbance from construction is generally considered to be local, temporary and similar in magnitude to common natural occurrences in the marine environment. These are the main reasons why impacts on benthos are sometimes considered local and limited to the devices' footprint on the seabed (e.g. mooring and anchoring systems).

Wave energy developments have potential to exhibit the same advantages as fish aggregating devices, artificial reefs and no-take zones. At the Swedish Lysekil test centre, WECs were judged to exhibit clear features of artificial reefs (ARs), with expected positive effects. The ability to design the WECs actively to enhance this effect was successfully demonstrated.

\section{Conclusions}

441 The review of the EIA documents produced shows that the receptors of primary interest are dependent on factors such as the local environmental landscape, the presence/absence of protected species and the regulatory authority under which the EIA is requested. It should be emphasised that the environmental impacts discussed here are potential impacts identified in the test centre EIAs and are not observed impacts.

A matter of concern in the assessment of environmental impacts is the cumulative impact from an expanding level of wave energy development taking place against a background of growing use of the marine environment (Maclean et al 2014). While there is some room for developers to partially mitigate this impact in the early stages of project development, this is a 
complex matter which is both technically and financially largely beyond the ability of any single developer to address adequately. For this reason, it is suggested that, although necessarily a component of individual project assessments, the issue of cumulative impacts should be comprehensively addressed strategically at the national level as part of SEA and/or in Maritime Spatial Planning and that it should be regularly reassessed.

It is clear that a large amount of scientific work is intrinsic to establishing the definitive effects and impacts of wave energy devices on the marine environment. Currently the majority of wave energy devices are deployed in dedicated test centres on a time limited and single unit basis. This limits the utility of the environmental information recorded and can result in effects and impacts being hypothesised only. To address this there is a need for a number of specific actions:

1. A dedicated research agenda for monitoring the environmental effects of devices on the marine environment and its communities;

2. Sharing of environmental data across disciplines and increased dissemination of EIA and related data so that knowledge of impacts can be developed;

3. Increased deployments of [multiple] devices in real sea conditions so that the hypothesised effects and impacts can be proved or disproved;

4. Standardised monitoring across test centres.

Whilst there will always be variation in the parameters considered during the EIA process, due to its site specific nature and cultural perception of risk, it would be advantageous to ensure consistency between methodologies used in measuring and monitoring environmental

471 parameters. The existence of test centres should facilitate such an approach given the same devices are often tested in different test centres. Indeed, test centres have a key role to play 
473

474

\section{References}

in providing environmental data and evidence on positive and negative impacts of early stage

wave energy device deployments that will help inform future development of the industry.

Abelson, A., Denny, M., 1997. "Settlement of marine organisms in flow". Annual Review of Ecology and Systematics 28, 317-339.

Cada, G. et al., 2007. Potential Impacts of Hydrokinetic and Wave Energy Conversion Technologies on Aquatic Environments. Fisheries 32: 174-181.

Cahill, B., 2013. Characteristics of the wave energy resource at the Atlantic marine energy test site. https://cora.ucc.ie/bitstream/handle/10468/1142/BCahill_Thesis.pdf?sequence=2

Clément, A., McCullen, P., Falcão, A., Fiorentino, A., Gardner, F., Hammarlund, K., Lemonis, G., Lewis, T., Nielsen, K., Petroncini, S., Pontes, M.-T., Schild, P.; Sjostrom, B.; Sorensen, H.C.; Thorpe, T., Wave energy in Europe: current status and perspectives, Renewable and Sustainable Energy Reviews, Volume 6, Number 5, October 2002, pp. 405-431(27)

Conley, D., Magagna, D., Greaves, D., Aires, E., Chambel Leitão, J., Witt, M., Embling, C., Godley, B., Bicknell, A., Saulnier, J., Simas, T., O’Hagan,A. M., O'Callaghan, J., Holmes, B., Sundberg, J., Torre-Enciso, Y., Marina, D., 2012. SOWFIA Deliverable D3.5. Report on the analysis of the Environmental Impact Assessment Experience for Wave Energy, Plymouth. Available at: www.sowfia.eu.

Croxall, J.P., 1987. Seabirds: Feeding Biology and Role in Marine Ecosystems. Cambridge University Press, Cambridge. 398 p. 
494

Cruz, J., 2008. Ocean Wave Energy. Current Status and Future Perspectives. Springer, 2008.

Cruz, E., Simas, T., 2012. Guidelines to a sustainable exploitation of offshore renewable energy - Account on seabird species. WavEC Offshore Renewables. Action 3, FAME Project Report, $42 \mathrm{p}$.

Defeo, O., McLachlan, A., Schoeman, D. S., Schlacher, T. A., Dugan, J., Jones, A., Lastra, M., Scapini, F., 2009. Threats to sandy beach ecosystems: a review. Estuarine, Coastal and Shelf Science 21, 1-12.

Dolman, S.J., Green, M., Simmonds, M. P., 2007. Marine Renewable Energy and Cetaceans. Report for the Scientific Committee. Whale and Dolphin Conservation Society, Chippenham, United Kingdom, SN15 1LJ UK. https://circabc.europa.eu/webdav/CircaBC/env/wind_nature/Library/meeting_10072008 /comments_contributions/wdcs/SC\%2059\%20E10\%20Renewables\%20Final.pdf (Accessed 11/1/16)

Falcão, A. F. de O., 2008. The Development of Wave Energy Utilisation. OES-IA Annual Report 2008. Available from: www.iea-oceans.org

Frid, C., Andonegi, E., Depestele, J., Judd, A., Rihan, D., Rogers, S. I., Kenchington, E., 2012. The environmental interactions of tidal and wave energy generation devices. Environmental Impact Assessment Review, 32, 133-139.

Gaines, S. D., Gaylord, B., Largier, J. L., 2003. Avoiding current oversights in marine reserve design. Ecological Applications 13(1), S32-S46. 
Gaylord, B., 2008. Hydrodynamic context for considering turbulence impacts on external fertilization. Biological Bulletin 214 (3), 315-318.

Gill, A.B., M. Bartlett, and F. Thomsen. 2012. "Potential interactions between diadromous fishes of UK conservation importance and the electromagnetic fields and subsea noise from marine renewable energy developments." Journal of Fish Biology 81 (2): 664-695.

Grecian, W., Inger, R., Attrill, M., Bearhop, S., Godley, B., Witt, M., Votier, S. 2010 Potential Impacts of Wave-Powered Marine Renewable Energy Installations on Marine Birds. IBIS Vol: 152, p 683-697

Haikonen, K., Sundberg, J. and Leijon, M., "Characteristics of the Operational Noise from Full Scale Wave Energy Converters in the Lysekil Project: Estimation of Potential Environmental Impacts", Energies. 2013; 6(5):2562-2582, doi:10.3390/en6052562

Harrington, N. and Andina-Pendás, I., 2008. Environmental impact and appraisal-planning consent for the South West of England Wave Hub. Underwater Technology, 27(4), pp.161-173.

Hildebrand, J., 2004. Sources of Anthropogenic Sound in the Marine Environment. Report to the Policy on Sound and Marine Mammals: An International Workshop. London.

Inger, R., Attrill, M. J., Bearhop, S., Broderick, A. C., Grecian, W. J., Hodgson, D. J., Mills, C., Sheehan, E., Votier, S. C., Witt, M. J., Godley, B. J., 2009. Marine renewable energy: potential benefits to biodiversity? An urgent call for research. Journal of Applied Ecology 46 (6): 1145-1153.

JRC (Joint Research Council), 2011. Review of Methodological Standrds Related to the Marine Strategy Framework Directive Criteria on Good Environmental Status. mcc.jrc.ec.europa.eu/documents/201409161352.pdf (Accessed 11/1/16) 
Judd, A., 2012. Guidelines for data acquisition to support marine environmental assessments of offshore renewable energy projects. CEFAS. Available from: http://www.marinemanagement.org.uk/licensing/groups/orelg.htm

Kadiri, M., Ahmadian, R., Bockelmann-Evans, B., Rauen, W., Falconer, R., 2012. A review of the potential water quality impacts of tidal renewable energy systems. Renewable and Sustainable Energy Reviews, 16(1): 329-341.

Koehl, M. A. R., 1996. When does morphology matter. Annual Review of Ecology and Systematics,

$$
\text { 27: 501-542. }
$$

Langhamer, O., Haikonen, K., Sundberg, J., 2010. Wave power-sustainable energy or environmentally costly? A review with special emphasis on linear wave energy converters. Renewable and Sustainable Energy Reviews, 14: 1329-1335.

Langhamer, O., Wilhelmsson D., Engström, J., 2009. Artificial reef effect and fouling impacts on offshore wave power. Estuarine, Coastal and Shelf Science 82: 426-432.

Langton, R., Davies, I. M., Scott, B. E., 2011. Seabird conservation and tidal stream and wave power generation: information needs for predicting and managing potential impacts. Marine Policy. 35: 623-630.

Lindeboom, H. J., Kouwenhoven, H. J., Bergman, M. J. N., Bouma, S., Brasseur, S., Daan, R., Fijn, R. C., de Haan, D., Dirksen, S., van Hal, R. et al., 2011. Short-term ecological effects of an offshore wind farm in the Dutch coastal zone; a complication. Environmental Research Letters, 6 (3): 035101.

Lucke, K., S. Storch, U. Siebert, J. Cooke, and S. Garthe. 2006. "Chapter 2.3.2. International exchange of experience on the assessment of the ecological impacts of offshore wind farms marine mammals." In: Zucco, C., Wende, W., Merck, T., Köchling, I., and Köppel, J. (Eds) 
Maclean, I.M., Inger, R., Booth, C.G., Embling, C.B., Grecian, W.J., Heymans, J.J., Plummer, K., Shackshaft, M., Sparling, C., Wilson, B. and Wright, L.J., 2014. Resolving issues with

Madsen, P. T., Wahlberg, M., Tougaard, J., Lucke, K., Tyack, P., 2006. Wind turbine underwater noise and marine mammals: implications of current knowledge and data needs. Marine Ecology Progress Series, 309: 279-295.

Magagna, D., Greaves, D., Conley, D., Aires, E., Chambel Leitão, J., Witt, M. J., Embling, C., Godley, B. J., Saulnier, J.-B., 2012. SOWFIA Deliverable D3.3. Interim WP3 Report.

Marqués, J., Torre-Enciso, Y., Marino, I., Pérez, G. and Zubiate, L., 2008, October. bimep-Biscay Marine Energy Platform. In Proc. of the 2nd International Conference on Ocean Energy (pp. 15-17).

McCluskie, A. E., Langston, R. H. W., Wilkinson, N. I., 2012. Birds and wave and tidal stream energy: an ecological review. The Royal Society for the Protection of Birds, Research report no. 42 .

Millar, D. I., Smith, H.C.M., Reeve, D. E., 2007. Modelling analysis of the sensitivity of shoreline change to a wave farm. Ocean Engineering, 34: 884-901.

Mouslim, H., Babarit, A., Clément, A. and Borgarino, B., 2009, September. Development of the french wave energy test site SEM-REV. In Proceedings of the 8th European wave and tidal energy conference, Uppsala, Sweden (pp. 31-35). 
Muñoz Arjona, E., Huertas-Olivares, C., Holmes, B., O'Hagan, A. M., Magagna, D., Greaves, D., 2012. Interim report on barriers, accelerators and lessons learned from all wave energy site experiences. SOWFIA Project Deliverable D.2.4. Plymouth. Available at: www.sowfia.eu.

Nowell, A. R. M., Jumars, P. A., 1984. Flow environments of aquatic benthos. Annual Review of Ecology and Systematics, 15: 303-328.

Ortega-Ortiz, J.G., Lagerquist, B., 2008. Report of the workshop on potential effects of wave energy buoys on marine mammals of the Oregon coast. Held October 9-10, 2008, in Portland, Oregon. Contract report to the Oregon Wave Energy Trust. Oregon State University Marine Mammal Institute, Newport, Oregon.

Palha, A., Mendes, L., Fortes, C. J., Brito-Melo, A., Sarmento, A., 2010. The impact of wave energy farms in the shoreline wave climate: Portuguese pilot zone case study using Pelamis energy wave devices. Renewable Energy, 35: 62-77.

Parwal,A, Remouit, F. Hong Y, Francisco, F. Castellucci, V. Hai, I. Ulvgård, L. Li, W. Lejerskog, E. Baudoin, A. Nasir, M. Chatzigiannakou, M, Haikonen, K, Ekström, R. Boström, C. Göteman, M. Waters, R. Svensson, O. Sundberg, J. Rahm, M. Strömstedt, E. Engström, J. Savin, A and Leijon, M. "Wave Energy Research at Uppsala University and The Lysekil Research Site, Sweden: A Status Update", Proceedings of the 11th European Wave and Tidal Energy Conference (EWTEC), Nantes, France, 6-11th Sept 2015

Patrício, Sofia, André Moura, and Teresa Simas. "Wave energy and underwater noise: State of art and uncertainties." OCEANS 2009-EUROPE. IEEE, 2009.

Pohle, G.W., Thomas, M. L. H., 1997. Monitoring protocol for marine benthos: intertidal and subtidal macrofauna. In: Marine and estuarine biodiversity monitoring protocols (G. 

Pohle, ed.), Report to the Ecological Monitoring and Assessment Network. Available from: http://www.gobookee.net/marine-benthos/

Richardson, W. J., Greene, C. R., Malme, C. I., Thomson, D. H., 1995. Marine Mammals and Noise. San Diego: Academic Press.

Rusu, E.,Guedes Soares, C. 2013. Coastal impact induced by a Pelamis wave farm operating in the Portuguese nearshore. Renewable Energy, 58: 34-49.

Scott, B.E., Langton, R., Philpott, E., Waggitt, J.J. 2014. Seabirds and marine renewables: Are we asking the right questions? In: Humanity and the Seas: Marine Renewable Energy and Environmental Interactions, Springer: http://link.springer.com/chapter/10.1007/978-94-017-8002-5 7

Shields, M. A., Woolf, D. K., Grist, E.P.M., Kerr, S.A., Jackson, A.C., Harris, R.E., Bell, M.C., Beharie, R., Want, A., Osalusi, E., Gibb, S.W., Side, J., 2011. Marine renewable energy: The ecological implications of altering the hydrodynamics of the marine environment. Ocean and Coastal Management, 54(1): 2-9.

Simas, T., Saulnier, J. B., O'Callagahn, J., Sundberg, J., Marina, D., Magagna, D., Embling, C., Bailey, I., 2013. Critical Environmental Impacts for Relevant Socio-economic Activities and Mitigation Measures Including Main Conclusions and Feedback Analysis from Workshop B and Analysis of the Stakeholder Survey. SOWFIA Project Deliverable D.4.4. Plymouth. Available from: www.sowfia.eu.

Simmonds, M. P., Brown, V.C., 2010. Is there a conflict between cetacean conservation and marine renewable-energy developments? Wildlife Research, 37: 688-694. 
Smith, H. C. M., Pearce, C., Millar, D. L., 2012. Further analysis of change in nearshore wave climate due to an offshore wave farm: An enhanced case study for the Wave Hub site, Renewable Energy, 40: 51-64.

Truebano, M., Embling, C., Witt, M., Godley, B., Attrill, M.,2013. The potential impacts of marine renewable energy on marine mammals. In Childs, M., \& Attrill, M. (Eds) Marine Renewables, Biodiversity and Fisheries. Friends of the Earth Policy Paper.

Wilson, B., Batty, R. S., Daunt, F., Carter, C., 2007. Collision risks between marine renewable energy devices and mammals, fish and diving birds. Report to the Scottish Executive. Scottish Association for Marine Science, Oban.

Witt, M. J., Sheehan, E. V., Bearhop, S., Broderick, A. C., Conley, D. C., Cotterell, S. P., Crow, E., 2012. Assessing Wave Energy Effects on Biodiversity: The Wave Hub Experience. Philosophical Transactions of the Royal Society A: Mathematical, Physical and Engineering Sciences 370 (1959) (January): 502-529. doi:10.1098/rsta.2011.0265. 
640 Tables

641 Table 1 - Type of monitoring studies carried out in each wave energy test centre analysed.

\begin{tabular}{|c|c|c|c|c|c|c|c|c|}
\hline & Test centres & AMETS & BIMEP & Lysekil & $\begin{array}{l}\text { Ocean } \\
\text { Plug }\end{array}$ & $\begin{array}{l}\text { SEM } \\
\text { REV }\end{array}$ & $\begin{array}{l}\text { Wave } \\
\text { Hub }\end{array}$ & Total \\
\hline Receptors & Country & Ireland & Spain & Sweden & Portugal & France & UK & \\
\hline \multirow{4}{*}{ 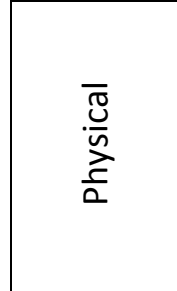 } & Bathymetry & & & $\checkmark$ & & $\checkmark$ & $\checkmark$ & 3 \\
\hline & Geomorphology & $\checkmark$ & & & $\checkmark$ & $\checkmark$ & $\checkmark$ & 4 \\
\hline & Hydrodynamics & $\checkmark$ & $\checkmark$ & & $\checkmark$ & $\checkmark$ & $\checkmark$ & 5 \\
\hline & Acoustics/Noise & & $\checkmark$ & $\checkmark$ & & & $\checkmark$ & 3 \\
\hline \multirow{5}{*}{$\begin{array}{l}\overline{0} \\
\frac{0}{00} \\
\frac{0}{0} \\
\frac{0}{0}\end{array}$} & Benthos & $\checkmark$ & $\checkmark$ & $\checkmark$ & $\checkmark$ & $\checkmark$ & $\checkmark$ & 6 \\
\hline & Fish \& Shellfish & & $\checkmark$ & $\checkmark$ & & & $\checkmark$ & 3 \\
\hline & Plankton studies & & & & & & $\checkmark$ & 1 \\
\hline & $\begin{array}{l}\text { Marine } \\
\text { Mammals }\end{array}$ & $\checkmark$ & $\checkmark$ & & $\checkmark$ & & $\checkmark$ & 4 \\
\hline & Sea birds & $\checkmark$ & & & $\checkmark$ & & $\checkmark$ & 3 \\
\hline \multirow{6}{*}{ 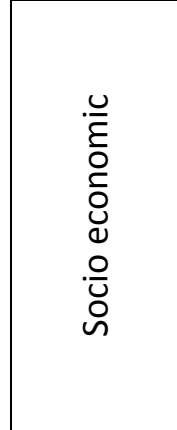 } & Landscape/Visual & $\checkmark$ & & & & & $\checkmark$ & 2 \\
\hline & Archaeology & & & $\checkmark$ & & & $\checkmark$ & 2 \\
\hline & Navigation & & & & & & $\checkmark$ & 1 \\
\hline & Fisheries & $\checkmark$ & & & $\checkmark$ & & $\checkmark$ & 3 \\
\hline & Economics & & & & & & $\checkmark$ & 1 \\
\hline & Tourism & & & & & & $\checkmark$ & 1 \\
\hline
\end{tabular}




\begin{tabular}{|c|c|c|c|c|c|c|c|}
\hline \multicolumn{2}{|r|}{ Receptors } & AMETS & BIMEP & LYSEKIL & $\begin{array}{c}\text { OCEAN } \\
\text { PIUG }\end{array}$ & SEM REV & $\begin{array}{l}\text { WAVE } \\
\text { HUB }\end{array}$ \\
\hline \multirow{3}{*}{ 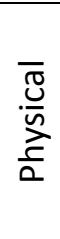 } & $\begin{array}{l}\text { Water quality and } \\
\text { ground water }\end{array}$ & $M$ & Co & Co & N/A & $M$ & Co \\
\hline & Physical processes & Co & $\mathrm{S}$ & Co & $\mathrm{N} / \mathrm{A}$ & Co & Co \\
\hline & $\begin{array}{l}\text { Air quality and } \\
\text { climate }\end{array}$ & Co & N/A & $\mathrm{N} / \mathrm{A}$ & N/A & N/A & $\mathrm{N} / \mathrm{A}$ \\
\hline \multirow{6}{*}{ 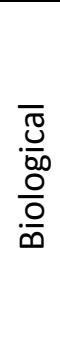 } & Marine mammals & $\mathrm{M}$ & $\mathrm{S}$ & Co & $\mathrm{S}$ & Co & Co \\
\hline & Seabirds & $\mathrm{M}$ & $\mathrm{M}$ & Co & $\mathrm{S}$ & Co & Co \\
\hline & \multirow{2}{*}{ Fish and shellfish } & \multirow{2}{*}{ N/A } & Noise: M & \multirow{2}{*}{ Co } & \multirow{2}{*}{ N/A } & \multirow{2}{*}{ Co } & \multirow{2}{*}{ Co } \\
\hline & & & EMF: M & & & & \\
\hline & \multirow[b]{2}{*}{ Benthos } & \multirow[b]{2}{*}{$M$} & Increased turbidity: M & \multirow[b]{2}{*}{ Co } & \multirow[b]{2}{*}{ N/A } & \multirow[b]{2}{*}{ Co } & \multirow[b]{2}{*}{ Co } \\
\hline & & & $\begin{array}{l}\text { Anchors and moorings' } \\
\text { dragging: } \mathrm{S}\end{array}$ & & & & \\
\hline
\end{tabular}

647 


\section{$648 \quad$ Figures}

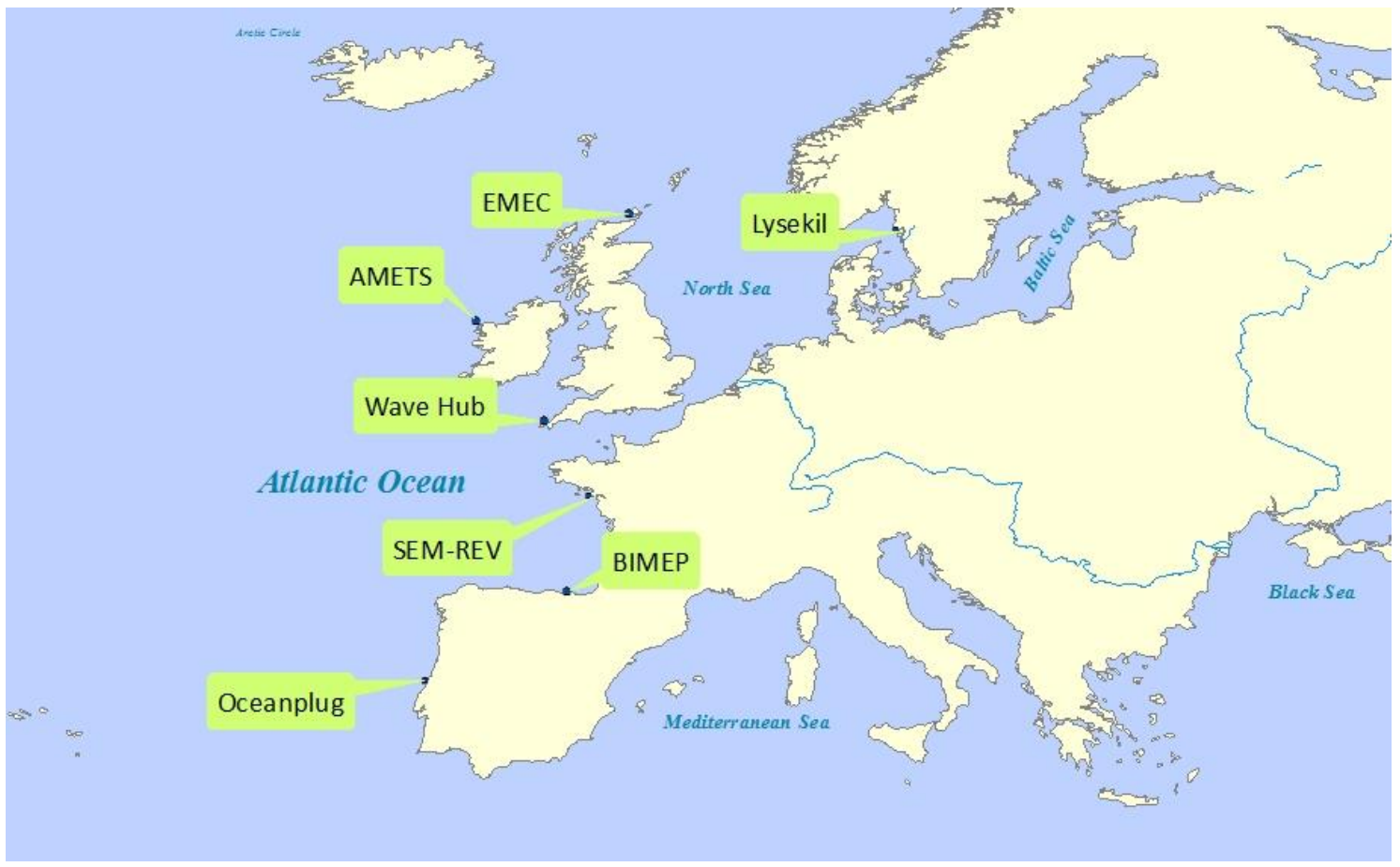

650 Fig. 1 - Location of the wave energy test centres in Europe. 